\title{
Biostratigraphy and biogeography of the Tethyan Cambrian sequences of the Zanskar Ladakh Himalaya and of associated regions
}

\author{
Suraj K Parcha \\ Wadia Institute of Himalayan Geology, 33 - Gen. Mahadeo Singh Road, Dehra Dun -248 001, INDIA \\ For correspondence, E-mail: parcha_1@rediffmail.com, parchask@wihg.res.in
}

The Cambrian sections studied so far exhibit $4 \mathrm{~km}$ thick and apparently conformable successions of Neoproterozoic and Cambrian strata in Zanskar - Spiti basins. The Cambrian sediments of this area are generally fossiliferous comprising trilobites, trace fossils, hylothids, cystoids, archaeocythid and brachiopod, etc. In parts of Zanskar - Spiti and Kashmir region rich trilobite fauna is collected from the Cambrian successions. The trilobites constitute the most significant group of fossils, which are useful not only for the delimination of various biozones but also for the reconstruction of the Cambrian paleogeography of the region.

The Zanskar basin together with a part of the Spiti basin forms not only the largest succession of the Tethyan sequences in the Himalaya, but also exposes one of the best developed sections. Thecompletesuccessions of rocks ranging in agefrom Precambrian to Eoceneareexposed in theZanskar area of Ladakh Himalaya. The Cambrian sediments in this basin areexposed in Tangzeeyogma, TangzeeKogma, Kuru, Purni - Phuktul, Kurgiakh sections of the Suru valley and Karsha section of the Zanskar valley.

On the basis of the faunal studies of icnofossils and on polymerid as well as agnostid trilobites, various faunal assemblage zones have been worked out from these sections.

The Himalayan Cambrian successions were whitherto considered to be deficient in agnostid trilobites. During recent years a variety of agnostid taxa have been reported from the Cambrian succession of the Zanskar basin. Agnostids constitute the most important index fossils for the global correlation of Cambrian successions. In the Zanskar Himalayan belt, the agnostid fauna is well preserved in the Middle Cambrian succession of Tangzee-Kuru- Purni-Phuktul and in the Kurgiakh sections of Lingti and Suru valleys. Preliminary studies reveal the presence of Baltagnostus, Clavagnostus, Peronopsis, Hypagnostus, Diplagnostus, Lejopygeand Goniagnostusa characteristic taxa of Hsuchuangian to Changhian stages of the Middle Cambrian.

In Spiti valley theagnostid fauna collected from theParahio section (Parcha 1999) is represented only by Peronopsis and Baltagnostus, which indicatestheH suchuangian stage of Middle. However, the agnostid fauna is not as widely present as in the Zanskar and Kashmir regions.

The record of Diplagnostus from Zanskar (Whittington 1986) and from northwestern part of Kashmir (Shah et al. 1995) issignificant becauseit marks the boundary between the Middle and LateCambrian. In theZanskar basin, the Diplagnostusisalso found associated with Lejopyge, which is moresignificant in order to establish theChanghian - Kushanian (LateMiddleCambrianearly Late Cambrian) boundary in this region. Diplagnostus is known to occur in the Lejopygelaevigata Zonein Australia. In the Yangliugang Group of Chiangan Belt in Sweden it extends from South Korea across southwestern China into North Vietnam. In
North America Diplagnostushas been reported from the Lejopyge laevigata Zone which characterizes the latest MiddleCambrian. In the Lingti valley of the Zanskar area the presence of Lejopyge $\mathrm{sp}$. is also of stratigraphic importance as it underlies the characteristic early LateCambrian faunal elements. In the Magam section of Kashmir the Diplagnostus occurs at the top of the Shahaspis (=Bolaspidela) Zone of Jell and Hughes(1997), that is overlain by the Damesella Zone, which contains characteristic faunal elements of Changhian early Late Cambrian age. The genus Damesella is also reported from the Kushanian stage in China, the Tiantzun Formation in Korea and from Agnostus pisiformisZone of the Outwood Formation in Britain.

The agnostid fauna reported from Kashmir and Zanskar regionsoccurs more or less at the same stratigraphic levels as in Australia, China, Kazakhstan, Sweden and North America. Therefore, it isuseful in demarcating theintrasystem boundaries within the Himalayan Cambrian successions of Zanskar and Kashmir and also for theglobal correlation.

In almost all well preserved Cambrian successions of the world most of the workers find the Middle - Late Cambrian boundary in between Lejopyge laevigata Zone and Agnostus pisiformis biostratigraphic Zone. In Kashmir as well as Zanskar basins, therefore, this boundary can be marked on the basis of the occurrence of genus Diplagnostus in association with Lejopyge. In the Spiti region however, these agnostids have not been reported so far.

Thetrilobitefauna of theHimalayan Cambrian successions ranges from Early Cambrian (Templetonian) stage to early Late Cambrian (Mindyallan) stages of Australia. The Early Cambrian fauna is well preserved both in the Lesser as well as Tethyan Himalayan successions. Whereas, the Middle to early Late Cambrian fauna so far is known from the Tethys Himalayan successions of Zanskar - Spiti, Kashmir, and Bhutan. The proposed biostratigraphic zonation is based on thetrilobitefauna collected so far from these regions. Thetrilobitefauna studied so far do not indicateany significant environmental change during the Cambrian period. So far no fossils have been reported from the upper part of Late Cambrian, whereas, latest part of Late Cambrian is marked by an angular unconformity in theZanskar - Spiti region and by the facies variation in Kashmir.

\section{References}

Jell, PA and NC Hughes. 1997. Himalayan Cambrian trilobites. Spec Papers in Paleontology 58: 113

Parcha, SK. 1999. Cambrian biostratigraphy in the Tethyan sequences of the Spiti Valley, Himachal Himalaya, India. Newsletters Stratigraphy 37(3): 177-190

Shah, SK, SK Parcha and AK Raina.1995. Additional agnostids from the Middle Cambrian of Kashmir. J Geol Soc India 45: 217-227

Whittington, HB. 1986. Late Middle Cambrian trilobites from Zanskar, Ladakh, northern India. Rivista Italiana dil Pal eontologiaeStratigrafia 92: 171-188 